\title{
EDITORIAL.
}

\section{PAZ, LA TAREA ES FORTALECER LA PARTICIPACIÓN SOCIAL Y POPULAR.}

\author{
Por: Tulio Gilberto Astudillo ${ }^{1}$, Alfonso Insuasty Rodriguez ${ }^{2}$
}

\section{Resumen.}

Asistimos a un momento histórico en Colombia, se marca posiblemente, el cierre de una cruenta confrontación armada de más de 50 años, entre las Farc-Ep y el gobierno Colombiano, este solo hecho ya de por sî, es bien importante, pero no suficiente.

\section{Palabras clave.}

paz, justicia social, transformación.

Es innegable que un acontecimiento importante para el país, para América Latina y para el mundo, lo es el actual proceso de negociaciones entre las Farc-Ep y el Gobierno de Colombia, se avanza hacia un cierre que se espera sea definitivo de dicha larga y aciaga confrontación armada. Tampoco se puede negar, que gracias a este proceso de negociaciones que avanza en la Habana, se ha logrado reabrir el debate nacional en torno a temas claves, estructurales, esenciales para hablar y construir una sociedad plural, diversa, en lucha permanente en defensa de sus territorios, del modelo de desarrollo que necesita el país, qué tipo de sociedad tenemos hoy y cuál es la que requerimos, que tipo de educación necesitamos, el papel de las Universidades, de la investigación académica en la transformación social, ampliar el discurso sobre víctimas, victimarios (empresarios, politicos, paramilitares, guerrilleros, militares) las razones de fondo de la barbarie que ha vivido Colombia, la necesidad de ahondar la participación real de las comunidades, en la toma de decisiones estratégicas de país, en la legitimidad o no, de una lucha armada, la estructura jurídica para una sociedad que se piensa la paz, etc., todos, temas necesarios a la hora de construir una paz estable y duradera, más allá del cierre de las confrontaciones armadas entre una insurgencia y quienes han ostentado ser Gobierno.

Se trata de un escenario complejo pero prudentemente esperanzador y tercamente desalentador.

Para explicar esta afirmación es necesario reconocer el contexto en el que estamos, reconocer el profundo y complejo conflicto social y político agudizado y sostenido por un permanente (fratricida) e inhumano conflicto Armado.

\footnotetext{
${ }^{1}$ Administrador de Universidad Abierta y a Distancia (Unad), Especialista en administración, adelanta estudios de Doctorado en el Instituto para el Pensamiento y la Cultura para América Latina (Ipecal - México). Investigador social, integrante del grupo de investigación Kavilando, miembro del colectivo de presos políticos Camilo Torres. Medellin - Colombia. Tulio.astudillo@kavilando.org

${ }^{2}$ Docente Investigador, director del grupo Gidpad de la Universidad de San Buenaventura Medellín, Editor de la Revista El Agora USB, e integrante del grupo autónomo de investigación para la transformación social Kavilando. Medellín, Colombia. Alfonso.insuasty@usbmed.edu.co.
} 
Hoy se habla de paz y eso es bueno, pero el mundo atiza la barbarie de la guerra por los recursos naturales, de los que como región, somos ricos; es un hecho que occidente, la civilización en crisis, vive una gran debacle económica que le exige ahondar en un modelo de desarrollo capitalista global que abusa del planeta con la explotación desmedida de los recursos, devorando el medio ambiente y con él, el tejido social y cultural construido por los habitantes del planeta. Se trata de una acelerada carrara por dominar territorios fáciles de explotar, para extraer sus recursos y dinamizar la maquina insaciable de la producción en escala ascendente, todo sobre la excusa de llevar la "modernidad", "la democracia" a esos países en vías de desarrollo o para sacarlos del atraso y por ende de la "pobreza".

Una politica acelerada de extracción de recursos naturales y humanos que ubica a algunos países de América Latina, incluida Colombia, en un buen lugar para hacer negocios por parte de multinacionales y el capital extranjero; bajos aranceles, débiles o nulas restricciones ambientales, gobiernos, legisladores y ejército; corruptos, facilitadores del saqueo y el despojo, destinados a limpiar territorios enteros para garantizar la implantación de megaproyectos y enclaves minero-energéticos. Toda está política, acompañada de una estrategia mediática, la creación, vía medios masivos de comunicación, de individuos solitarios y consumidores voraces, que reactivan el flujo del crédito y del capital.

Como reacción de las comunidades y pueblos en defensa de sus territorios y del planeta, se viven y dinamizan luchas sociales por todos los rincones del continente, reivindicando la soberanía, la defensa de la vida, del medio ambiente, redes que se articulan paulatinamente siendo poder real, se trata de movimientos que van en dos lógicas, una que pretende vía gobierno re-direccionar el progreso, fomentando la redistribución de la riqueza y la nacionalización de la producción estratégica, pero manteniendo el esquema moderno de desarrollo, y otro sector que propende por el desarrollo de procesos distintos al hegemónico neoliberal, que se interesa y realiza experiencias de relacionamiento integral con la naturaleza, en ordenes socio-naturales que permiten que los humanos y los no-humanos podamos co-existir de manera armónica, transcendiendo el modelo donde lo no- humano está bajo el dominio y sometimiento de lo humano. Visión que lleva a repensar conceptos como el de "modernidad" "desarrollo" "economía" y reconocer la importancia de lo común, lo público a través de la construcción de colectivos, comunidades fuertes, autónomas articuladas sobre el presupuesto que construir otro mundo posible, no solo es necesario, sino imperativo.

El proceso de paz actual, que vive Colombia, tiene en su haber, un entorno complejo, la tradicional clase dirigente se ha empeñado en hacer creer que el país no tiene otra salida que aceitar la maquinaria del desarrollo occidental, dejándonos en el lugar más bajo de la actividad económica; el extractivismo y para ello parece requiere una Paz a la medida. Así mismo el reto de desmontar la violencia estructural como mecanismo de acción política y de acumulación de riqueza, conquistando las garantías que permitan el tránsito del país hacia una democracia real.

Hoy emergen en el mundo, en América Latina y por ende en Colombia, nuevas y sentidas luchas sociales, el medio ambiente, el agua, la soberanía alimentaria, la soberanía en el uso de los recursos, el subsuelo y el sobresuelo, los nacimientos de agua, los páramos, los ecosistemas, el consumo responsable, el comercio justo, lo que implica construir 
valores como la solidaridad, el respeto por la diferencia, sociedades plurales coloridas libres y articuladas en una lucha común, el derecho a existir y ser en relación con otros autorregulándose.

Nuevas y viejas luchas sociales y populares, se renuevan, fortalecen y articulan. El actual proceso de negociación debe desencadenar la articulación del movimiento social y popular, activar la lucha y repensar la formación de sujetos políticos que comprendan el contexto histórico y el quehacer del momento, rescatando su papel en la construcción de nueva sociedad, de recuperar la utopía. Debe propiciar una racionalidad que además de propender por la unidad de la izquierda a partir de una agenta articuladora, que recupere los sujetos de la izquierda desde sus particularidades y diversidad.

Entre todas estas reflexiones, surge una pregunta clave para quienes deambulamos por el llamado mundo académico y universitario: ¿cuál es el papel que viene jugando y debe jugar la Universidad en esta construcción de una paz estable y duradera?

Se supone que la Universidad en esencia es el lugar donde se piensa de manera crítica la sociedad, donde se piensa la transformación constante de la sociedad hacia condiciones dignas, humanas, ambientalmente responsables. Eso es lo ideal y lo rescatable, pero hoy, en Colombia, asistimos a unas instituciones que han burocratizado la producción del saber, atrapándola en la lógica del mercado académico y la métrica positivista. La Universidad de Mercado ha quedado atrapada en la falaz relación Universidad-Empresa-Estado, una relación en la que la Gran Empresa y el Estado actúan al unísono, quedando la Universidad cual sumisa sirvienta a merced de la financiación vía proyectos, quien financia pone las condiciones, limitando la libertad de producción y de pensamiento. Nada más analizar la manera como Colciencias se ha estructurado, cerrándole especio a las Ciencias Sociales y Humanas, lo mismo Publindex, delegando su tarea a bases bibliográficas como Escopus e Isi, quienes definen qué es conocimiento, qué es ciencia, en un país plural, diversos, pareciera que no hubiésemos superado las discusiones en torno a la ciencia, la verdad, el saber, la realidad.

Aún y este panorama, surgen diversas voces y propuestas organizativas que se pelean otro modelo educativo, otro modelo de medición y estandarización de los que se supone es Ciencia, es una publicación científica, vale la pena mencionar que resurgen gracias al actual proceso de negociación Redes como la RedUnipaz que viene asumiendo esta tarea disidente de pensarse otras maneras de ser de la Universidad, recuperar la palabra y el sentir de Maestros como Orlando Fals Borda, de uno de los fundadores de la facultad de Sociología en Colombia Camilo Torres Restrepo, al sentar postura frente al papel real que debe jugar la universidad en un país como Colombia, construir conocimiento desde lo propio para mejorar las condiciones de vida, dignidad, soberanía, bien y buen vivir de quienes habitan el territorio Colombiano.

En el año 2012, se realizó el VI Congreso Nacional y I Internacional, en el 2015 se realizará el VII Congreso Nacional y II Internacional de paz, en la ciudad de Ibagué, para pensar, discutir, articular, la academia con las organizaciones sociales y populares en la idea de construir un país que se piensa a sí mismo y propone acciones concretas de transformación. Esa es la razón de esta publicación, aportar en la discusión y el debate de país desde lo que somos y queremos ser. 


\section{Referencias Bibliográficas.}

Balvin Alvarez, J., \& Insuasty Rodriguez, A. (2008). Victimas Violencia y Despojo. Medellín: Litoimpacto.

Bastidas, W., \& Insuasty Rodriguez, A. (2010). Victimas en Medellín. EL AGORA USB, 367397.

Bonilla González, R. (2005). Problemas económicos una salida integral a la crisis. Bogotá: Fescol.

Boron, A. (2004). Estado capitalismo y democracia en América Latina. Quito: Clacso.

Fajardo, M. d. (2012). Panorama Minero de Colombia. Recuperado el 13 de 2 de 2014, de Razón Pública: http://www.razonpublica.com/index.php/econom-y-sociedad-temas29/3468-panorama-minero-de-colombia.html

Insuasty Rodriguez, A. (2012). ¿crear ambiente para la Paz? Cepa(16), 41-46. Obtenido de http://revistacepa.weebly.com/uploads / 1/3/3/7/13372958/crear_ambiente_para_la_ paz.pdf

kavilando. (2012). Reflexiones sobre el mandatar a nivel local. Kavilando revista virtual,http:/ /www.kavilando.org/site/index.php?option=com_content\&view=arti cle\&id=1205:reflexiones-sobre-el-mandatar-a-nivel-local-congreso-de-los-pueblos\&catid=42: editorial\&Itemid $=84$.

Pax Christi. (2000). Red Nacional de Iniciativas Ciudadanas por la Paz y contra la Guerra (REDEPAZ). Obtenido de paxchristi.net: http://www.paxchristi.net/memberorganizations/colombia/ 190

RedProdepaz. (2010). Red Prodepaz. Obtenido de redprodepaz.org.co: http://www. redprodepaz.org.co/programas-de-desarrollo-y-paz

Semana. (2 de 2014). Seis millones de víctimas deja el conflicto en Colombia. Recuperado el 15 de 2 de 2014, de semana.com: http://www.semana.com/nacion/articulo/victimasdel-conflicto-armado-en-colombia/376494-3 


\title{
EDITORIAL.
}

\section{PEACE, THE TASK IS TO STRENGTHEN THE SOCIAL AND POPULAR PARTICIPATION.}

\author{
By Tulio Gilberto Astudillo \& Alfonso Insuasty Rodriguez.
}

\begin{abstract}
.
We are witnessing a historic moment in Colombia. It possibly marks the end of a bloody armed confrontation of more than fifty years, between FARC-EP and the Colombian government. This very fact per se is very important, but not enough.
\end{abstract}

\section{Key Words.}

Peace; Social Justice, and Transformation.

It is undeniable that an important event for the country, Latin America, and the world, is the current negotiation process between FACR-EP and the Colombian government, we are moving toward an end, in such a long and fateful armed confrontation. We cannot deny either, thanks to the negotiation process, which is being carried out in Havana, the national debate around key, structural, and essential issues, which have been re-opened in order to talk and to build a plural, diverse society, in a permanent fight in defense of its territories, of the development model that the country requires, what kind of society we have today and which one is the one we require, what kind of education we need, the role played by the universities, the one about the academic research in the social transformation, as well as to enlarge the discourse on victims and aggressors (entrepreneurs, politicians, paramilitaries, guerrilla groups, and militaries); the underlying reasons of the brutality that Colombia has gone through, the need to delve into the real participation of communities, in the strategic decision-making of the country, to the legitimacy or not, of an armed conflict, the juridical structure for a society that thinks about peace, etc.; all of these are necessary issues in order to build a stable and lasting peace, from just beyond the cease of the armed confrontation between the insurgency and those who have held the position of being Government.

It is about a complex scenario, but not prudently promising and stubbornly discouraging. In order to explain this statement, it is necessary to recognize the context we are in, as well as the deep and complex social and political conflict, aggravated and supported by a permanent (fratricide) and inhumane armed conflict.

Today, we talk about peace and that is good, but the world revives the barbarity of war for natural resources, which as a region, we are rich; it is a fact that the western world, the civilization in crisis, is experiencing a great economic disaster, which requires of it to deepen in a global capitalist development model, which abuses the planet with the excessive exploitation of the resources, devouring the environment, and with it, the social and cultural fabric built by the inhabitants of the planet. It is an accelerated race to dominate territories, which are easy to be exploited, in order to extract their resources and to boost 
the insatiable machine of production, on ascendant scale, with the sole excuse of taking "modernity," "democracy," to those underdeveloped countries or just to take them out of the backwardness, hence of "poverty."

An accelerated extraction policy of natural and human resources, which places some Latin American countries, including Colombia, in a good place to do business by multinationals and foreign capital; low tariffs, weak or no environmental restrictions, corrupted governments, legislators, and army; facilitators of pillage and plunder, intended for cleaning whole territories to guarantee the implementation of mining and energy megaprojects and enclaves. All this policy is accompanied by a media strategy, creation, via mass media, of voracious consumer and solitary individuals, who revive the flow of credit and capital.

As a reaction of communities and peoples in defense of their territories and that of the planet, social struggles are experienced and invigorated, in every part of the continent, claiming sovereignty, the defense of life, the environment, these are networks dealing with movements divided into two logics, one which is government geared aims to re-direct progress by boosting the redistribution of wealth and the nationalization of the strategic production, but keeping the modern scheme of development, and another sector that tends to the development of different processes to the hegemonic neoliberal model that cares about and performs comprehensive relationships with nature experiences, within socio-natural orders, which let humans and non-humans co-exist harmoniously, going beyond the model where the non-human is under the domination and the subjugation of the human, being a vision leading to rethink concepts like "modernity," "development," and "economics" and to recognize the importance of the ordinary, the public through the construction of the collective; strong, autonomous communities articulated on the premise that to build another possible world, is not only necessary, but imperative.

The current peace process, which Colombia is going through, has to its credit, a complex environment, the traditional ruling class has endeavored to make people believe that the country has no other way out that to oil the machinery of the Western development, leaving us in the lowest place of the economic activity; the extractive activity and this seems to require peace, as demanded. Likewise, the challenge of dismantling the structural violence as a mechanism of political action and accumulation of wealth, conquering the necessary guarantees that let the country move towards a real democracy.

Today, new and deep social struggles, the environment, water, food sovereignty, sovereignty in the use of resources, the subsoil and the surface, the springs of water, the moorlands, the ecosystems, the responsible consumption, the fair trade, what implies to build values such as solidarity, the respect for difference, free colorful and articulated pluralistic societies, in a common fight, the right to exist and to be in relation to others, in a self-regulatory manner, emerge in the world, in Latin America and thus, in Colombia.

Old and new social and popular struggles are renewed, strengthened, and articulated. The current negotiation process should trigger the articulation of the social and popular movement, activate the struggle and rethink the formation of political subjects who may understand the historical context and the task of the moment, rescuing its role in the construction of a new society, recover the utopia. It should lead to a rationality, which in 
addition to promote the unity of the Left, starting from an articulating agenda, can recover the subjects on the Left, based on their peculiarities and diversity.

Among all these reflections, a key question, for those who wander by the so-called academic and university world, arises: what is the role that is being played and must play the University in this construction of a stable and lasting peace?

It is assumed that the University is essentially the place where society is critically thought, where the constant transformation of society is thought towards decent, humane, environmentally responsible conditions. That would be the ideal and redeemable thing to do, but today, in Colombia, we are witnessing institutions, which have bureaucratized the production of knowledge, trapping it in the logic of the academic market and the positivist metrics. The University of the Market has been trapped in the fallacious relationship among University-Enterprise-State, a one in which Large Enterprises and the State act in unison, leaving the University, as a submissive maid, at the mercy of funding for projects; the one who finances sets the conditions, limiting the freedom of production and thinking. Just analyze the way as Colciencias has been structured, not giving opportunities to the Social and Human Sciences, the same is true with Publindex, delegating its task to bibliographic databases, such as Scopus and Isi, responsible for defining what knowledge is, what science is, in a pluralistic and diverse country, it seems as if we had not gotten over the discussions about science, truth, knowledge, and reality.

Even this panorama, and diverse voices and organizational proposals arise, which fight for another educational model, another measurement model, and standardization of those which are supposed to be science, is a scientific publication. It is worth mentioning that thanks to the current negotiation process, networks like "RedUnipaz," is taking on this dissident task, of thinking other ways of being of the University, to recover the word and the feelings of Masters like Orlando Fals Borda, one of the founders of the Faculty of Sociology in Colombia, and Camilo Torres Restrepo, by taking a stand on the real role that the university should play in a country like Colombia, to build knowledge from a personal perspective in order to better the living conditions, dignity, sovereignty, well and good living of those who inhabit the Colombian territory.

In 2012, the Sixth National and the First International Peace Congress took place, in 2015, the Seventh National and II international Peace Congress will be held, in the city of Ibague, in order to think, to discuss, and to articulate the academy with the social and popular organizations with the purpose of building a country that thinks itself and proposes concrete actions of transformation.

That is the reason for this publication, which is to contribute to the discussion and the debate of a country, based on what we are and what we want to be. 


\section{References}

Balvin Alvarez, J., \& Insuasty Rodriguez, A. (2008). Victimas Violencia y Despojo. Medellin: Litoimpacto.

Bastidas, W., \& Insuasty Rodriguez, A. (2010). Victimas en Medellin. EL AGORA USB, 367397.

Bonilla González, R. (2005). Problemas económicos una salida integral a la crisis. Bogotá: Fescol.

Boron, A. (2004). Estado capitalismo y democracia en América Latina. Quito: Clacso.

Fajardo, M. d. (2012). Panorama Minero de Colombia. Recuperado el 13 de 2 de 2014, de Razón Pública: http://www.razonpublica.com/index.php/econom-y-sociedad-temas29/3468-panorama-minero-de-colombia.html

Insuasty Rodriguez, A. (2012). ¿crear ambiente para la Paz? Cepa(16), 41-46. Obtenido de http://revistacepa.weebly.com/uploads/1/3/3/7/13372958/crear_ambiente_para_la_ paz.pdf

kavilando. (2012). Reflexiones sobre el mandatar a nivel local. Kavilando revista virtual,http:/ /www.kavilando.org/site/index.php?option=com_content\&view=arti cle\&id=1205:reflexiones-sobre-el-mandatar-a-nivel-local-congreso-de-los-pueblos\&catid=42: editorial\&Itemid $=84$.

Pax Christi. (2000). Red Nacional de Iniciativas Ciudadanas por la Paz y contra la Guerra (REDEPAZ). Obtenido de paxchristi.net: http://www.paxchristi.net/memberorganizations/colombia/ 190

RedProdepaz. (2010). Red Prodepaz. Obtenido de redprodepaz.org.co: http://www. redprodepaz.org.co/programas-de-desarrollo-y-paz

Semana. (2 de 2014). Seis millones de víctimas deja el conflicto en Colombia. Recuperado el 15 de 2 de 2014, de semana.com: http://www.semana.com/nacion/articulo/victimasdel-conflicto-armado-en-colombia/376494-3 